\title{
Mortality and disability among cotton mill workers
}

\author{
R-S Koskela, M Klockars, E Järvinen
}

\begin{abstract}
The mortality and disability of cotton mill workers were studied in five Finnish cotton mills. The population under study comprised all 1065 women exposed to raw cotton dust who had been hired between 1950 and 1971. The minimum exposure period was five years. For the study on disability, the cohort was followed up until the end of 1981 . The follow up period for the mortality analysis was from 1950 to 1985. At the end of 1981 the observed number of prevalent disability pensions for respiratory disease was 15 , whereas 3.9 were expected $(p<0.01)$ on the basis of the national figures for women. There were 46 musculoskeletal diseases $(27.7$ expected, $p<0.01)$, of which 24 were osteoarthritis (14.5 expected) and 13 rheumatoid arthritis (6.6 expected). The incidence rates of disability pensions were calculated for the period 1969-81. Comparison of incidence rates between cotton mill workers and the Finnish female population showed excessive rates for both respiratory diseases $(\mathbf{p}<0.001)$ and musculoskeletal diseases (p $<0.01$ ), with an excess of new cases of rheumatoid arthritis $(p<0.05)$. By the end of 1985 the number of person-years was 31678 and the number of deaths 95 . The standardised mortality ratios for the total period of follow up (1950-85) showed no excess for respiratory diseases. Mortality from cardiovascular diseases was also lower than expected. The observed number of tumours was 33 , the corresponding expected number $32 \cdot 0$. Thirteen tumours were in the digestive organs (6.6 expected, $p<0.05)$ and three were lung cancers (1.9 expected). Five workers had died from renal disease; the expected number was $1.5(\mathbf{p}<0.05)$.
\end{abstract}

Although respiratory morbidity associated with exposure to cotton dust has been extensively studied, relatively few studies have been published of the long term consequences for disability and mortality of

Institute of Occupational Health, Topeliuksenkatu 41 a A, SF-00250 Helsinki, Finland

R-S Koskela, M Klockars, E Järvinen former cotton textile workers. ${ }^{1}$ Increased mortality of workers exposed to cotton dust has been reported for $\overrightarrow{0}$ cardiovascular, renal, and respiratory diseases ${ }^{2-5}$ (and $\vec{\overrightarrow{ }}$ J B L Tombleson, International conference of the $\vec{\omega}$ permanent commission and international association on occupational health, Bulgaria, 1971), but later studies have not indicated such an excessive mortality. ${ }^{6-8}$ Inconsistent results have been reported for cancer mortality, with low lung cancer death rates $\dot{\omega}$ having been observed in several studies. ${ }^{679}$ Excess $\stackrel{\infty}{\oplus}$ mortality from stomach cancer and oral cancer may 응 be seen in the British decennial occupational mortality tables, ${ }^{5}$ and from gastrointestinal cancer $c$ and urinary cancer in the cohort study reported by Henderson and Enterline. ${ }^{6}$ Excess mortality from nasal adenocarcinoma has also been observed among textile workers. ${ }^{10}$

We have previously reported on the mortality and disability of female cotton mill workers with a minimum exposure period of five years in the follow up period 1950-73. ${ }^{11}$ A slight excess of malignant neoplasms $\left(115^{\circ}{ }_{0}\right.$ of the expected value) and renal diseases was observed. Disability due to diseases of the respiratory system and to musculoskeletal diseases slightly exceeded that of the general female population of the same age.

The purpose of this study was to examine mortality patterns in the same cohort during the follow up period 1950-85, the incidence of new disability pensions between 1969 and 1981, and the prevalence of these pensions calculated at the end of 1981 for 1065 women exposed to raw cotton for at least five years between 1950 and 1971 .

\section{Subjects and methods}

SUBJECTS

The population comprised all women exposed to raw cotton who had been hired between 1950 and 1971 by the five Finnish cotton mills, altogether 1065 women. The minimum exposure period was five years.

The workers' names, dates and places of birth, and their work histories at the various cotton mills were taken from the employers' personnel records. Altogether $99.7 \%$ of the workers were successfully traced through the Population Data Register. The cohort was then compared with national registers on death, disability, and free medication for chronic diseases.

The follow up period for the mortality analysis was 1950-85. The causes of death were ascertained from

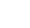


death certificates according to the eighth revision of the International Classification of Diseases (ICD). ${ }^{12}$ The calculations of the death rates were based on the primary cause of death. Other (secondary) causes were also coded for the study of disease combinations and case analyses. The death certificates were obtained from the Central Statistical Office of Finland.

New disability pensions awarded to cotton mill workers between 1969 and 1981 were studied and the prevalent number of people receiving these pensions was calculated as of the end of 1981. The causes of disability, coded according to the International Classification of Diseases, were obtained from the Finnish Social Insurance Institution. People with diseases for which medication was free under the national sickness insurance law were followed up until the end of 1981; these data were also obtained from the Social Insurance Institution.

A questionnaire study on occupational history, smoking habits, alcohol consumption, and diagnosed diseases was carried out for the whole cohort (for those still alive or for the next of kin) at the end of 1985. The response rate was $73.2 \%$. We compared these data with a similarly selected group of 398 female paper box assembly workers not exposed to dust; among these workers the response rate was $77 \cdot 4^{\mathrm{o}}{ }_{0}$.

\section{BASIS FOR COMPARISON}

The expected numbers of deaths were calculated from the official statistics on causes of death for the general female population in $1977,{ }^{13}$ the median year of all deaths in the cohort. ${ }^{14}$ The prevalent numbers (as of 31 December 1981) and incidence rates (from 1969 to 1981) for the disability pensions of the cotton mill workers were compared with the corresponding figures for the Finnish female active population during the same period..$^{15}$ The prevalent numbers of workers granted free medication by the end of 1981 were compared with the corresponding expected numbers for the general female population of Finland. ${ }^{16}$

The prevalence of reported diseases, smoking, and alcohol consumption was compared with that of the non-exposed comparison group.

\section{EXPOSURE}

A survey of dust concentrations in the five cotton mills had been performed in $1972 .{ }^{17}$ The mean dust concentrations were $2 \mathrm{mg} / \mathrm{m}^{3}$ for bale opening, $3.3 \mathrm{mg} / \mathrm{m}^{3}$ for carding, $1.8 \mathrm{mg} / \mathrm{m}^{3}$ for spinning, and $2 \mathrm{mg} / \mathrm{m}^{3}$ for the winding phases of work. About $80 \%$ of the subjects worked under conditions where the dust concentrations were higher than the Finnish hygienic standard $\left(1 \mathrm{mg} / \mathrm{m}^{3}\right)$.

According to complete exposure histories, $15 \%$ of the workers had been engaged mostly in bale opening, picking, and carding, $70^{\circ}{ }_{0}$ in spinning and rolling, and $15^{\circ}$ o in other raw cotton working phases. The median exposure time was 28.0 years (range 5-38) for living workers and $22 \cdot 4$ years (range 5-29) for workers who had died.

More than five years of occupational exposure to some potential carcinogen was reported for 69 workers $\left(6 \cdot 5^{\circ}\right)$. We considered the following exposures or activities as potentially carcinogenic: manmade mineral fibres, leather, rubber, dyes, solvents, mineral dusts, glues, fur processing, and work in the pulp and paper and metal industries. Only one of the 33 patients with cancer in the cohort had had potential carcinogic exposure (in dyeing). Information on smoking habits was obtained for $74^{\circ}{ }^{\circ}$ of the cohort. Of these, $21^{\circ}{ }_{0}$ (791 women) were smokers and $79^{\circ}{ }_{0}$ never-smokers. The age specific smoking habits did not differ much from those of the comparison group. Of the 33 cases of cancer, 15 were verified as never-smokers. Alcohol consumption was similar among cotton mill workers and the comparison group.

\section{STATISTICAL ANALYSIS}

In the analysis of the mortality pattern age specific observed and expected numbers of deaths were computed for the causes of death using national figures and standardised mortality ratios. The observed and expected numbers were subdivided into five year periods of follow up and calculated according to years since entry (latency periods). The observed age specific and cause specific numbers of deaths were tested by the Poisson distribution model against the corresponding expected numbers. ${ }^{18}$

The age specific and cause specific observed and expected numbers of subjects receiving disability pensions on 31 December 1981 were calculated. The incidence rates of new disability pensions were calculated for the period 1 January 1969-31 December 1981. The Poisson distribution model was used to test the observed prevalent numbers against the expected. ${ }^{18}$ The Poisson model was chosen as an approximative method to compare a small population against a large national population. The incidence rates were tested by the Mantel-Haenszel $\chi^{2}$ test for incidence data. ${ }^{19}$

The observed age specific and cause specific numbers of subjects receiving free medication were calculated at the end of 1981 and compared with the expected numbers at the same date for the general female population of Finland. The Poisson distribution was used to compare the observed and expected numbers.

The age specific occurrences of previously diagnosed diseases reported on the questionnaire were tested by the Mantel-Haenszel $\chi^{2}$ test. The comparisons between the cotton mill workers and the non-exposed group were made by stratifying the 
workers into ten year age classes (for the age range 35-64).

A nested case-referent study design was used for a detailed analysis of rheumatoid arthritis, bronchial asthma, and renal diseases. Cotton mill workers with these diseases-recorded on death certificates or in the disability pension register or in the register of people receiving free medication-were included as cases. Two referents, matched for year of birth, were chosen for each case. Lifetime doses of cotton dust exposure were calculated for the cases and referents by using the occupation specific dust concentrations in each mill in 1972 multiplied by a score of exposure time $(2=5-9,3=10-19,4=\geqslant 20$ years). The mean of the lifetime dose of each two referents was used for the comparison. The breaking points of the dose distributions were defined on the basis of the distribution of the subjects with rheumatoid arthritis and their referents. The first breaking point, six, was the point from which the distribution of cases with rheumatoid arthritis started to differ from that of the referents; the second breaking point, 10, was the median of the rest of the cases and referents in the distribution.

\section{Results}

\section{MORTALITY}

By the end of 1985 the number of person-years was 31678 and of deaths 95 (table 1). The SMR for the total period of follow up (1950-85) showed no excess for respiratory diseases. Mortality from cardiovascular diseases was also lower than expected. The observed number of tumours was 33, the corresponding expected value being 32.0 . Thirteen tumours were in the digestive organs (expected $6 \cdot 6$, $\mathrm{p}<0.05)$. The excess came from the workers aged 45 or older, and was mainly caused by stomach cancer. The number of stomach cancers was six, the expected value was $3 \cdot 2$ (all the cases were in the age range 35-64, for which the expected value was $2 \cdot 0$, $\mathrm{p}<0.05)$. Only three lung cancers were observed in

Table 1 Observed (Obs) and expected (Exp) numbers of certain causes of death and the SMR for the cohort of cotton mill workers at the end of 1985 . The period of entry was defined as 1950-71

\begin{tabular}{lcrr}
\hline Cause of death & Obs & Exp & $S M R$ \\
\hline Cardiovascular diseases: & 37 & 48.3 & 77 \\
Ischaemic heart disease & 16 & 21.6 & 74 \\
Cerebrovascular disease & 13 & 14.3 & 91 \\
Tumours: & 33 & 32.0 & 103 \\
Lung cancer & 3 & 1.9 & 158 \\
Cancer of the digestive organs & $13^{\star}$ & 6.6 & 197 \\
Respiratory diseases & 4 & $5 \cdot 1$ & 78 \\
Renal diseases & $5^{\star}$ & 1.5 & 333 \\
Violent deaths & 7 & $11 \cdot 2$ & 63 \\
Total & 95 & 110.3 & 86 \\
\hline
\end{tabular}

${ }^{\star} \mathrm{p}<0.05$, Poisson distribution.
Table 2 Distribution of deaths from cancer

\begin{tabular}{|c|c|}
\hline Primary cause of death & No \\
\hline Lung cancer & 3 \\
\hline Gastrointestinal cancer: & 13 \\
\hline Oesophagus & \\
\hline Stomach & \\
\hline Biliary duct & \\
\hline Liver & \\
\hline Colon & \\
\hline Rectum & \\
\hline Genital cancer & 6 \\
\hline Breast cancer & 5 \\
\hline Multiple myeloma and lymphoma & 3 \\
\hline Ocular melanoma & 1 \\
\hline Glioma of the brain & 1 \\
\hline Renal cancer & 1 \\
\hline Total & 33 \\
\hline
\end{tabular}

the whole cohort. Table 2 shows the distribution of various types of cancer. Five workers had died fronf renal disease, whereas the expected number was $1.5-$ $(\mathrm{p}<0.05)$.

\section{MORBIDITY}

Disability

The incidence rates of disability pensions were calculated for the period 1969-81 (fig 1). Comparisono of incidence rates between cotton mill workers and the Finnish female population showed excessive rates for both respiratory diseases $(p<0.001)$ an musculoskeletal diseases $(\mathrm{p}<0.01)$; the difference was explained by rheumatoid arthritis $(p<0.05)$.

At the end of 1981,116 workers were receiving disability pensions. The observed number oE prevalent disability pensions for respiratory disease? was 15 , whereas the expected number was 3.50 $(\mathrm{p}<0.001)$ on the basis of the national figures fo $\frac{\mathbb{D}}{5}$ women at the same date (table 3 ). Eleven of the 150 cases were caused by bronchial asthma and three by pneumoconiosis; one was caused by allergic rhinitiso The number of musculoskeletal diseases was 46 (27. expected, $\mathrm{p}<0.01$ ), of which 24 were osteoarthritio (14.5 expected) and 13 rheumatoid arthritis $(6 \cdot \bar{q}$ expected). Mental disorders, altogether 29 cases constituted the greatest disease group among the remaining 55 disability pensions.

\section{Free medication}

At the end of 1981 the cotton mill workers suffereof from a total of 334 chronic diseases entitling them to free medicines; the expected number was 354 on the basis of age specific figures for the Finnish female population at the same date.

The number of subjects receiving free medication for treatment of congestive heart failure and hyper $\vec{D}$ tension was lower than expected $(\mathrm{p}<0 \cdot 01)$. Fo bronchial asthma the observed number was highe? than expected $(\mathrm{p}<0.01)$ (table 4$)$. The distribution of the cases of bronchial asthma into different age classes was similar to that of the expected number? 


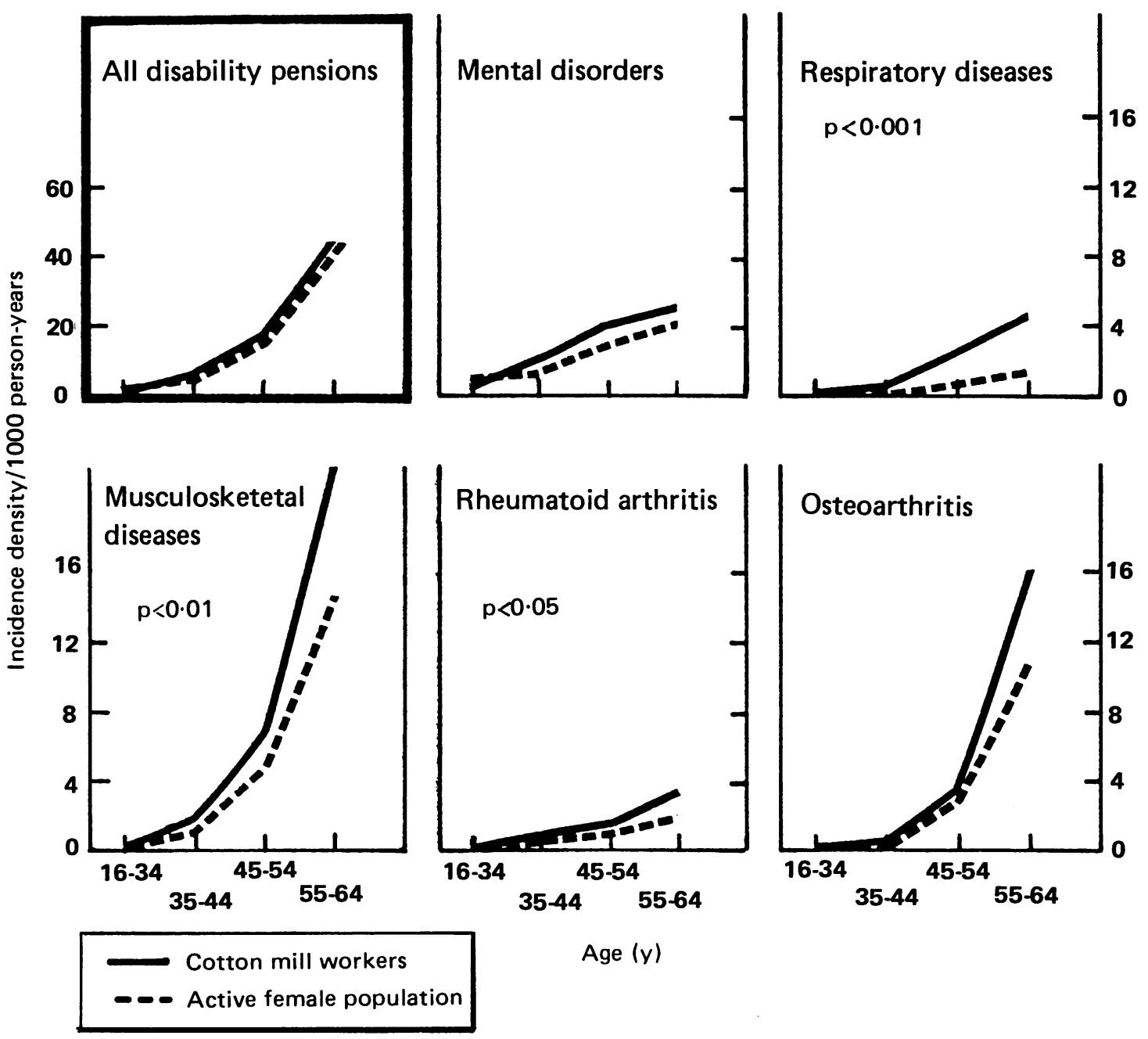

Figure 1 Incidence densities of new disability pensions among cotton mill workers during $1969-81$.

but showed an excess in the age classes of 45-64. The number of subjects receiving free medication for rheumatoid arthritis and pyelonephritis was not more frequent among cotton mill workers than among the general female population.

Table 3 Observed (Obs) and expected (Exp) numbers of certain causes of disability on 31 December 1981. The expected numbers are calculated on the basis of age specific figures for the Finnish female general population at the same date

\begin{tabular}{llr}
\hline Disease & $O b s$ & Exp \\
\hline Respiratory diseases & $15^{\star \star \star}$ & 3.9 \\
Musculoskeletal diseases: & $46^{\star \star}$ & $27 \cdot 7$ \\
Rheumatoid arthritis & $13^{\star}$ & 6.6 \\
Osteoarthritis & $24^{\star}$ & 14.5 \\
Mental disorders & 29 & 30.1 \\
\hline
\end{tabular}

${ }^{\star} \mathrm{p}<0.05 ;{ }^{\star \star} \mathrm{p}<0.01 ;{ }^{\star \star \star} \mathrm{p}<0.001$ Poisson distribution.
Table 4 The numbers (Obs) of certain diseases with the entitlement to free medication from national sickness insurance on 31 December 1981. The expected numbers (Exp) were calculated from national age specific rates for the same date

\begin{tabular}{lcc}
\hline Disease & Obs & Exp \\
\hline Diabetes & 22 & $22 \cdot 0$ \\
Schizophrenia & 17 & $13 \cdot 9$ \\
Congestive heart failure & $35^{\star \star}$ & $55 \cdot 1$ \\
Rheumatoid arthritis & 26 & $23 \cdot 5$ \\
Bronchial asthma & $29 \star \star$ & $17 \cdot 6$ \\
Chronic pyelonephritis & 14 & $19 \cdot 2$ \\
Hypertension & 131 & $146 \cdot 4$ \\
\hline
\end{tabular}

$\star \star p<0.01$, Poisson distribution.

\section{Reported diseases}

The occurrence of diagnosed diseases reported by the cotton mill workers at the end of 1985 was compared 
with that reported by the non-exposed comparison group (table 5). The cotton mill workers reported statistically significantly more cases of lung tuberculosis and bronchitis than the comparison group. No other pronounced differences were found in the group of respiratory diseases. The occurrence of cardiovascular diseases was similar in both groups. In cotton mill workers the occurrence of rheumatoid arthritis was 1.7 times that of the comparison group. On the other hand, there was less aching or pain in the neck and shoulders among cotton mill

Table 5 Odds ratios (OR) and significances of the differences in the occurrence of diagnosed diseases reported on the questionnaire by the cotton mill workers and by the nonexposed comparison group

\begin{tabular}{lll}
\hline Disease & & \\
\hline Respiratory diseases: & $\chi^{2}(1)$ \\
\hline Tuberculosis of lung & & \\
Pleuritis & 7.9 & $5.68^{\star}$ \\
Bronchitis & 1.4 & 0.08 \\
Emphysema & 1.8 & $6.93^{\star}$ \\
Bronchial asthma & 0.7 & 0.00 \\
Cardiovascular diseases: & 1.0 & 0.01 \\
Heart diseases & 1.0 & 0.00 \\
Cerebrovascular diseases & 1.3 & 0.06 \\
Hypertension & 0.8 & 0.83 \\
Musculoskeletal diseases: & 1.7 & 1.40 \\
Rheumatoid arthritis & 0.7 & $5.76 \star$ \\
Ache or pain in neck and shoulders & 0.9 & 0.49 \\
Ache or pain in arms & 0.8 & 1.00 \\
Sciatica and/or low back pain & 1.0 & 0.00 \\
Ache or pain in legs & 0.9 & 1.90 \\
Neoplasms: & 2.2 & 2.63 \\
Benign neoplasms & 1.4 & 2.00 \\
Malignant neoplasms & 1.3 & 0.13 \\
Renal diseases & & \\
Diabetes & &
\end{tabular}

${ }^{\star} \mathrm{p}<0.05,{ }^{\star \star} \mathrm{p}<0.01$, Mantel-Haenszel $\chi^{2}$ test. workers than among the comparison group. Lower? frequencies were also found for other musculo- $\vec{F}$ skeletal diseases. Malignant neoplasms and renal diseases were more often reported by the cotton mill workers than by the comparison group.

Nested case-referent analysis of rheumatoid arthritis, bronchial asthma, and renal diseases

Table 6 and fig 2 show the number and proportional $\vec{\circ}$ distribution of cases and referents in relation tolifetime exposure to dust.

\section{RHEUMATOID ARTHRITIS}

The cases of rheumatoid arthritis and their matched referents were distributed similarly up to a dust. exposure index of six (table 6). The difference ${ }_{\omega}$ between the series became evident in the higher ${ }_{+}^{\infty}$ categories of exposure. The cases were exposed moreo than the referents (fig 2) but the difference was not statistically significant. The most exposed casesc were equally distributed throughout the age range of all cases. The high lifetime exposure score was attributed to both high dust concentrations and long $\vec{\oplus}$ exposure periods.

The median age at onset of rheumatoid arthritis among the cases was 47 (range 29-64) and the median interval between the start of cotton mill work and the onset of rheumatoid arthritis was 20 years (range 2-36).

BRONCHIAL ASTHMA

In the lowest index class of lifetime exposure cases of bronchial asthma were less frequent than in the referents; but in the medium class, opposite was the case. This effect of selection may also be seen in fig 2 .
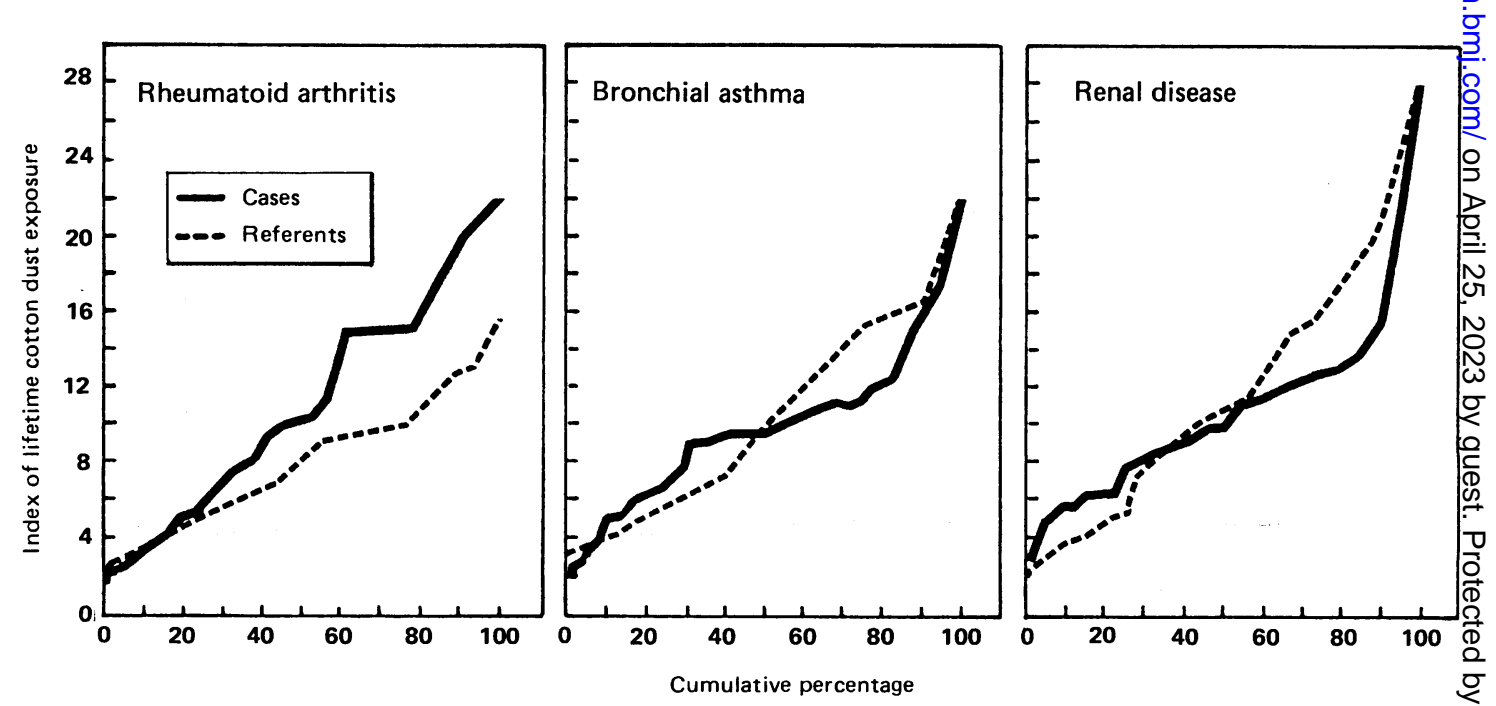

Figure 2 Cumulative distribution of lifetime cotton dust exposure among cases of rheumatoid arthritis, bronchial asthma, ando renal disease and their age matched referents. 
Table 6 Distribution of subjects with rheumatoid arthritis, bronchial asthma, or renal disease and their age matched referents in lifetime cotton dust exposure categories

\begin{tabular}{|c|c|c|c|c|c|c|c|c|c|c|c|c|}
\hline \multirow{2}{*}{$\begin{array}{l}\text { Disease } \\
\text { Index of lifetime cotton dust exposure }\end{array}$} & \multicolumn{4}{|c|}{ Rheumatoid arthritis } & \multicolumn{4}{|c|}{ Bronchial asthma } & \multicolumn{4}{|c|}{ Renal disease } \\
\hline & $<6$ & $6-10$ & $>10$ & $\Sigma$ & $<6$ & $6-10$ & $>10$ & $\Sigma$ & $<6$ & $6-10$ & $>10$ & $\Sigma$ \\
\hline $\begin{array}{l}\text { Cases } \\
\text { Referents }\end{array}$ & $\begin{array}{l}19 \\
19\end{array}$ & $\begin{array}{r}7 \\
13\end{array}$ & $\begin{array}{r}10 \\
4\end{array}$ & $\begin{array}{l}36 \\
36\end{array}$ & $\begin{array}{l}19 \\
13\end{array}$ & $\begin{array}{r}9 \\
14\end{array}$ & $\begin{array}{r}9 \\
10\end{array}$ & $\begin{array}{l}37 \\
37\end{array}$ & $\begin{array}{r}18 \\
9\end{array}$ & $\begin{array}{r}5 \\
13\end{array}$ & $\begin{array}{r}9 \\
10\end{array}$ & $\begin{array}{l}32 \\
32\end{array}$ \\
\hline
\end{tabular}

*The mean of lifetime dose of dust of the two referents.

The difference did not exist in the highest exposure category. The most exposed cases had worked in high dust concentrations (eight of the nine cases had been exposed to a dust concentration of $\geqslant 5 \mathrm{mg} / \mathrm{m}^{3}$ ) but did not have the longest exposure period; neither were they the oldest cases.

Sixty two per cent of all cases and $69 \%$ of the referents had never smoked. Seven of the nine most exposed cases had never smoked. Two of the nine most highly exposed cases had byssinosis and one had emphysema in addition to bronchial asthma.

\section{RENAL DISEASES}

The distribution of cases of renal disease according to lifetime exposure to cotton dust differed from that of the referents in the range of low and medium exposure (table 6, fig 2). The heaviest exposure scores among the cases were due to high dust concentrations rather than long exposure periods.

\section{Discussion}

The results of this study are discussed in terms of the formation criteria of a cohort with an exceptionally high selection of jobs. The cohort was restricted to workers who had been exposed for at least five years and had first started raw cotton work between 1950 and 1971. During this period, altogether some 9000 women had started this type of work but only 1065 of them were still engaged in it five years later. The turnover of employees within two weeks was one in ten and within three months one in four; only $53 \%$ of the new employees continued working with raw cotton for at least one year and only $13 \%$ for at least five years. ${ }^{11}$ The effect of health selection was evident both in the cross sectional health survey of current cotton mill workers in $1970-2^{20}$ and in the earlier follow up study of mortality and morbidity. ${ }^{11}$

The effect of cigarette smoking on the disease processes associated with exposure to cotton dust has been discussed repeatedly. ${ }^{21}$ In the present study we judged the possible confounding effect of smoking to be low on the basis of the following observations: firstly, the proportion of smokers among the Finnish female population during 195070 was low; secondly, the smoking habits of the cotton mill workers were practically the same as those of Finnish female cohorts in the same period ${ }^{22}$; thirdly, in the light of the replies to the questionnaire, smoking among our cotton mill workers did not differ from that of the comparison population of paper box assembly workers; fourthly, only $45 \%$ of all cases of cancer were verified as smokers; and, finally, in the case-referent analysis of rheumatoid arthritis, bronchial asthma, and renal diseases the smokers in the case series did not associate with any particular score level of lifetime exposure to dust. It is unlikely that even a synergistic effect of cotton dust as exposure to organic dust and smoking would have produced excess mortality from lung cancer with the construction of latency phases between 14 and 35 years in this cohort.

Further, the potential confounding lifetime occupational exposure may be regarded as negligible because of the low frequencies and the lack of concentration in any particular group of disease-for instance, cancer.

\section{RESPIRATORY DISEASES}

There was no evidence of increased total mortality or mortality from respiratory diseases among cotton mill workers. This agrees with several earlier studies..$^{6-823}$ Mortality is unlikely to be affected, because there is no evidence of exposure to cotton dust, even after many years, producing emphysema or interstitial fibrosis or any other permanent pathological changes of the lung. ${ }^{23}{ }^{24}$ Nevertheless, excess morbidity from some other non-fatal respiratory diseases - for example, bronchial asthma and chronic bronchitis-in the cohort may decrease the mortality from respiratory diseases. Both these factors cause underreporting of pulmonary diseases on the death certificates of cotton mill workers. Furthermore, the cohort of workers had thinned down in the course of five years to about $13 \%$ of its original size. It is therefore conceivable that individuals with atopy, respiratory tract sensitivity, or any other type of constitution making them likely to develop symptoms shortly after starting work almost certainly leave their jobs during the first five years. This healthy worker effect might also explain the decreased number of observed deaths from cardiovascular diseases (SMR 77).

Our results on disability and free medication 
indicate serious long term, work related morbidity among cotton mill workers, although the total number of disability pensions due to respiratory diseases included some acute respiratory disorders. The excess of bronchial asthma, both intrinsic and non-occupational, work related asthma, and bronchitis suggests the development of progressive respiratory abnormalities. ${ }^{825}$ This is consistent with the study of Schachter et $a l^{26}$ showing a higher prevalence of both obstructive and restrictive lung function abnormalities among cotton textile workers than among the control subjects. Cigarette smoking is associated with a higher prevalence of byssinosis ${ }^{127}$ and complicates the understanding of long term effects of exposure to dust. In the present study a confounding effect of smoking is unlikely (see above).

\section{RHEUMATOID ARTHRITIS}

There is evidence that inhaled dusts, including asbestos, talc particles, carbon dust, and silica, may affect extrapulmonary organs. ${ }^{28} 29$ An association between occupational exposure to inhaled dusts and rheumatoid arthritis has been observed for granite workers exposed to silica. ${ }^{30}$ There also seems to be a link between our epidemiological results on long term occupational exposure to cotton mill dust and the pathogenetic aspects of rheumatoid arthritis. It has been suggested that it is not merely the concentration of cotton dust but rather the concentrations of Gram-negative bacteria contaminating the cotton and flax and their endotoxins that are responsible for the development of both acute and persistent respiratory symptoms and the byssinosis syndrome. ${ }^{31-33}$ Many of the factors proposed as an explanation for the inflammatory reaction of byssinosis-for example, endotoxins, immune complexes, bacterial proteolytic enzymes, and arachidonic acid metabolites-are inflammatory modulators with pronounced systemic consequences, even for the joints. $^{3435}$

The pathogenetic role of environmental dusts may involve a lowered resistance to airway or gastrointestinal micro-organisms, including mycobacteriathat is, to infectious agents that might contribute to the development of rheumatoid arthritis. A similar association has been observed between rheumatoid arthritis and exposure to granite dust. ${ }^{30}$

\section{RENAL DISEASE}

Although mortality from renal disease exceeded the expected values significantly, the observed number of cases was low. Our study showed excess mortality from renal diseases before 1973. Hence, a later change in the renal disease pattern and in the treatment of these maladies may explain the disappearance of renal disease as the main cause of death during the second follow up period. In 1951
Schilling and Goodman, however, also noted af excess of deaths from nephritis among cotton: workers. ${ }^{4}$ Renal diseases were no more frequen⿳亠口冋. among people receiving disability pension or freo medication, and no excess number of individualô reported the occurrence of renal disease in the

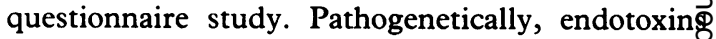
have been shown to act synergistically witha nephrotoxic agents. ${ }^{36}$ Endotoxins may have ${ }^{\infty}$ causative role in some types of acute renal failure ${ }^{37} \overrightarrow{30}$ and in experimental animals endotoxins enhance the development of antibody mediated glomerulow nephritis. ${ }^{39}$

\section{CANCER}

In general, low mortality from respiratory cancer has been reported among cotton textile workers. ${ }^{62} \mathrm{E}$ There are conflicting data on the incidence of cance of the digestive and urinary tract among these workers. ${ }^{56}$

In the present study the increase in the number of gastrointestinal and lung cancers among worker exposed to cotton dust is of interest. Physically, the ultimate target organs for inhaled dust are both theo respiratory and the digestive tracts. A similar excess of cancer mortality due to lung and stomach cancero has also been observed among workers exposed to inorganic dusts such as silica. ${ }^{40}$ In none of thesē instances is the pathogenetic mechanism understood\% Consequently, our results do not support the hypothesis that the endotoxins in cotton dust provid $\overrightarrow{5}$ protection against the development of cancer. ${ }^{9}$

\section{Conclusion}

Exposure to cotton dust induces a certain disease $\mathscr{\mathbb { D }}^{\mathbb{D}}$ pattern. Satisfactory detection depends on cohort definition and duration of follow up ${ }^{41}$ as well as on the quantity of exposure. The first symptoms of respiratory diseases are often masked by high turn over rates. This healthy worker effect may delayo manifestation of chronic respiratory diseases of decrease mortality, or both, from those diseases in cohort. So far as cancer is concerned, many dus exposed industrial cohorts-for instance, foundryer workers, granite workers, coal miners-first shown an increased risk of stomach cancer and duringu the subsequent follow up periods, risk of lung cancer. ${ }^{40-44}$ Furthermore, cotton dust also appears to increase the morbidity of renal disease and rheumatoid arthritis. For these diseases, the commons pathogenetic denominator may be the systemic effects of inflammatory mediators induced byo exogenous dusts.

We thank Ms A Rossi, for collecting the question $\frac{D}{0}$ naire data, Ms R Lukinmaa for coding the occu pational histories, and Mr J Seitsamo, for the्ठ 
data processing. We express our sincere thanks to Ms A-M Bolander, Swedish Statistics, for her help in tracing those cohort members who had emigrated to Sweden, and Dr Matti Koponen, for his advice with the estimation of lifetime dust exposures. We also thank the Population Register Centre for the data on status and addresses, the Social Insurance Institution for the data on disability and free medication, and the Central Statistical Office of Finland for the data on causes of death.

1 Merchant JA, Ortmeyer C. Mortality of employees of two cotton mills in North Carolina. Chest 1981;79:6-10.

2 Caminta BH, Baum WF, Neal PA, Schneiter R. A review of the literature relating to affection of the respiratory tract of individuals exposed to cotton dust. (Public Health bulletin No 297.) Washington: US Government Printing Office, 1949.

3 Schilling RSF. Byssinosis in the British cotton textile industry. L, Med Bull 1950;7:1-2, 52-6.

4 Schilling RSF, Goodman N. Cardiovascular disease in cotton workers: part I. Br J Ind Med 1951;8:77-90.

5 Registrar General's decennial supplement England and Wales 1961. Occupational mortality tables. London: HMSO, 1971.

6 Henderson V, Enterline PE. An unusual mortality experience in cotton textile workers. J Occup Med 1973;15:717-9.

7 Daum S, Heinemann H, Damon F, Richter E, Selikoff 1 . Mortality patterns among textile workers. In: Cotton dust, proceedings of a symposium sponsored by the American Conference of Governmental Industrial Hygienists, Cincinnati, 1974. Cincinnati: ACGIH, 1975:1-5.

8 Berry G, Molyneux MKB. A mortality study of workers in Lancashire cotton mills. Chest 1981;79:11-5.

9 Enterline PE. Mortality among asbestos workers. Ann NY Acad Sci 1965;132:156-65.

10 Acheson ED, Cowdell RH, Rang E. Adenocarcinoma of the nasal cavity and sinuses in England and Wales. Br J Ind Med 1972;29:21-30.

11 Koskela R-S, Luoma K, Häkkinen I. Mortality, disability and turnover of cotton mill workers. Työterveyslaitoksen tutkimuksia 150. (Institute of Occupational Health study reports No 150.) Helsinki: IOH, 1979. (In Finnish with English summary.)

12 National Board of Health. Tauti- ja kuolinsyyluokitus (WHO. The international statistical classification of diseases, injuries and causes of death, . Helsinki: NBH, 1969.

13 World Health Organisation. World health statistics annual 1977. Vital statistics and causes of death. Geneva: WHO, 1981.

14 Koskela R-S, Klockars M, Järvinen E, Rossi A, Kolari PJ. Cancer mortality of granite workers 1940-1985. In: Simonato L, Fletcher AC, Saracci R, Thomas T. Occupational exposure to silica and cancer risk. Oxford: Oxford University Press, 1990:43-53. (IARC sci publ No 97.)

15 Social Insurance Institution. Kansaneläkelaitoksen tilastollisio vuosikatsauksia 1981. ( Statistical review of the Social Insurance Institution, 1981). Helsinki: SII, 1982. (Kansaneläkelaitoksen julkaisuia T3:10C.)

16 Social Insurance Institution. Kokonaan korvattaviin läakkeisiin oikeuttavat sairaudet 31.12.1981. I Statistics on diseases conferring entitlement to free medicines under national sickness insurance, 31 December 1981). Helsinki: SII, 1982. (Kansaneläkelaitoksen julkaisuja T6:16.)

17 Koponen M. Dust investigation in Finnish cotton mills in 19701974. Työterveyslaitoksen tutkimuksia 119. (Institute of Occupational Health study reports No 119.) Helsinki: IOH, 1975. (In Finnish with English summary.)

18 Lentner C, ed. Geigy scientific tables. Vol 2. 8th ed. Basle: CibaGeigy, 1982

19 Rothman KJ, Boice JD Jr. Epidemiologic analysis with a programmable calculator. Boston: Epidemiology Resources, Inc, 1982.

20 Häkkinen I. Byssinosis in Finnish cotton mills. Työterveyslaitoksen tutkimuksia 121. (Institute of Occupational Health study reports No 121.) Helsinki: IOH, 1975. (In Finnish with English summary.)

21 Wegman DH. Evaluation of epidemiologic approaches to the study of lung disease related to cotton dust exposures. $\mathrm{Am} \mathrm{J}$ Ind Med 1987;12:661-75.

22 Martelin T. Development of smoking habits in Finland. Helsinki: National Board of Health, 1984. (Series original reps $1 / 1984$.)

23 Elwood PC, Pemberton J, Merrett JD, Carey GCR, McAulay IR. Byssinosis and other respiratory symptoms in flax workers in Northern Ireland. Br J Ind Med 1965;22:27-37.

24 Moran TJ. Emphysema and other chronic lung disease in textile workers: an 18-year autopsy study. Arch Environ Health 1983;38:267-76.

25 Beck GJ, Maunder LR, Schachter EN. Cotton dust and smoking effects on lung function in cotton textile workers. $\mathrm{Am} \mathrm{J}$ Epidemiol 1984;119:33-43.

26 Schachter EN, Maunder LR, Beck GJ. The pattern of lung function abnormalities in cotton textile workers. Am Rev Respir Dis 1984;129:523-7.

27 Fox AJ, Tombleson JBL, Watt A, Wilkie AG. A survey of respiratory disease in cotton operatives. Part II Symptoms, dust estimations, and the effect of smoking habit. $\mathrm{Br} J$ Ind Med 1973;30:48-53.

28 Holt PF. Transport of inhaled dust to extrapulmonary sites. $J$ Pathol 1981;133:123-9.

29 Koskela R-S, Klockars M, Järvinen E, Kolari PJ, Rossi A. Mortality and disability among granite workers. Scand $J$ Work Environ Health 1987;13:18-25.

30 Klockars M, Koskela R-S, Järvinen E, Kolari PJ, Rossi A. Silica exposure and rheumatoid arthritis: a follow up study of granite workers 1940-81. Br Med J 1987;294:997-1000.

31 Rylander R. Bacteria as etiological agents in byssinosis and other lung disease. Eur J Respir Dis 1982;63:34-46.

32 Rylander R, Morey P. Airborne endotoxin in industries processing vegetable fibers. Am Ind Hyg Assoc J 1982;43:811-2.

33 Rylander R, Haglind P, Lundholm $M$. Endotoxin in cotton dust and respiratory function decrement among cotton workers in an experimental cardroom. Am Rev Respir Dis 1985;131: 209-13.

34 Wahl LM, Wahl SM, Mergenhagen SE, Martin GR. Collagenase production by endotoxin-activated macrophages. Proc Natl Acad Sci USA 1974;71:3598-601.

35 Peeters-Joris C, Vaes G. Degradation of cartilage proteoglycan and collagen by synovial cells. Stimulation by macrophages under activation by phagocytosis, lymphocyte factors, bacterial products or other inflammatory stimuli. Biochim Biophys Acta 1984;804:474-86.

36 Gardner KD, Reed WP, Evan AP, Zedalis J, Hylarides MD, Leon AA. Endotoxin provocation of experimental renal cystic disease. Kidney International 1987;32:329-34.

37 Wardle EN. Endotoxinaemia and the pathogenesis of acute renal failure. $O J$ Med 1975;174:389-98.

38 Graeff H, Mitchell PS, Beller F. Fibronolytic enzyme system of the kidney related to renal function after infusion on endotoxin in rabbits. Lab Invest 1968;19:169-73.

39 Shibata S. On the significance of latent period of masugi nephritis in rabbits. I Glomerulonephritis induced in a short period by the combination of nephrotoxic antiserum and bacterial endotoxin. Jpn J Exp Med 1969;39:277-86.

40 Koskela R-S, Klockars M, Järvinen E, Kolari PJ, Rossi A Cancer mortality of granite workers. Scand $J$ Work Environ Health 1987;13:26-31.

41 Koskela R-S, Järvinen E, Kolari PJ. Effect of cohort definition and follow-up length on occupational mortality rates. Scand $J$ Work Environ Health 1984;10:311-6.

42 Koskela R-S, Hernberg S, Kärävä R, Järvinen E, Nurminen M Mortality study of foundry workers. Scand $J$ Work Environ Health 1976;2:suppl 1:73-89.

43 Miller BG, Jacobsen M. Dust exposure, pneumoconiosis, and mortality of coalminers. Br J Ind Med 1985;42:723-33.

44 Wright WE, Bernstein L, Peters JM, Garabrant DH, Mack TM Adenocarcinoma of the stomach and exposure to occupational dust. Am J Epidemiol 1988;128:64-73.

Accepted 30 October 1989 